\title{
A STUDY OF JOURNAL PUBLICATION DIVERSITY WITHIN THE AUSTRALIAN INFORMATION SYSTEMS SPHERE
}

\author{
CARMINE SELLITTO \\ Centre for International Corporate Governance Research \\ Victoria University \\ Melbourne, Victoria, Australia. \\ Email: Carmine.Sellitto@vu.edu.au
}

\begin{abstract}
This study reports on research that examined DEST data from 14 Australian universities to identify the diversity of journal outlets in the information systems (IS) area. Across a total of 60 years of academic publishing output, 1449 journal articles were evaluated to identify 649 different journals in which IS-related articles were published. The most popular journals used by Australian academics to publish ISrelated articles were the Lecture Notes in Computer Science $(\mathrm{N}=94)$ in the computer science area, with the Australasian Journal of Information Systems $(\mathrm{N}=25)$ being the most popular journal in the pure and business IS sphere. The study also examined publishing output against a set of 50 previously highly rated IS journals and concluded that the average annual publication of articles in these highly rated journals occurred at a very low rate. The research appears to be one of the first studies to use historical DEST data to report journal diversity in the Australian IS-sphere.
\end{abstract}

\section{INTRODUCTION}

Journal publication has evolved as the accepted manner in which the academic community disseminates knowledge, an important emphasis being placed on appropriate peer-reviewed journals (Sharplin and Mabry 1985; Baker 2000; Tenopir and King 2001). Academic publication tends to not only set the foundations for furthering a discipline, but is also used as a gauge of scholarly success - where an important aspect of researcher productivity can be reflected by their scholarly publication record (Ramsden 1994). An appropriate journal publication record will invariably influence university promotion and tenure, professional standing amongst peers and external industry groups, as well as impacting on research grant success (Katerattanakul et al. 2005). Hence, for many scholars, the decision to publish their research entails selecting appropriate outlets that provides a suitable conduit that will allow both exposure of their work and also facilitate personal recognition. In terms of publication opportunities, Steele (2006) indicates that there are some 22,000 peer-reviewed journals available to academics in which to disseminate their work- many being English language based and having a northern hemisphere focus. With respect to identifying the IS 
journal outlets, an evolving and recognised journal compendium is the Index of Information Systems Journals (Lamp 2004) that lists over 500 active journal outlets in which researchers can publish their work. Furthermore, the Association for Information Systems (AIS) - the body representing the global IS community - lists and rates over 100 journals as potential publishing outlets for the IS scholar (http://www.isworld.org/csaunders/rankings.htm).

From an Australian perspective, little if any research has been undertaken on the academic productivity of Australian-based academics that publish in the information systems area. Recent commentary by Lamp (2006) highlighted a significant increase in available information systems (IS) related publication outlets (This paper uses the term IS in the same context as Lamp (2006) one that is based on the broad range of journals available to academics for publishing IS-related topics). Moreover, Lamp (2006) highlighted the importance of having journals recognised and listed by the Australian Government's Department of Education, Science and Training (DEST) in order for Australian academics to claim reward for their publication productivity. Although his practice has been recently discontinued, the remnant DEST listing of journals still provides a powerful reference that identifies publications that have met certain peer-review quality attributes. Furthermore, considering that the traditional funding of Australian universities is directly related to a university's academic research quantum, it is surprising that there is no centrally maintained ledger or database of past productivity output that details the different types of journals in which ISrelated articles are published. Indeed, the submission of data to government by universities is a mere summary of the annual publications, with the more informative data remaining with the universities. Arguably, with a shifting focus within the Australian university sphere onto the quality of academic output - this study takes the view that future journal output values within the IS area needs to have at least a baseline point of reference that is reflected by the recently published academic worksallowing some form of future comparison. Given the non-centralised availability of research quantum data, this paper reports on research that sourced and evaluated Australian DEST data to examine aspects of journal publication diversity for academics publishing in IS related areas.

\section{IS JOURNAL PUBLICATION— SOME RANKING AND RATING STUDIES}

The number of journals publishing computing and information systems related articles has increased dramatically over the last 50 years (Lamp 2006). Many of these journals have evolved to focus exclusively on pure-IS research, whilst other journals proportionally publish IS-related scholarly works. Conversely, IS academics have, over the last 20 years or so, published IS-related work in the journals of various allied disciplines (Peffers and Ya 2003). Indeed, the broad sphere of IS activities can be part of a number of related computer and information science areas ranging from engineering, computer science through to business-commerce related information systems (Clarke 1999; Clarke 2006). Given this activity base, there is general recognition that IS-related research can be disseminated through a broad spectrum of publishing outlets.

In recent years various computing and IS journal ranking systems have been published in an endeavour to highlight and evaluate appropriate publication outlets. Within academic realms, journal ranking or rating has an implied notion associated with quality - a journal of higher rank being perceived as having greater quality - a factor that can shape manuscript submission behaviour and one that has been reported as influencing an academic's standing (Vokurka 1996; Mylonopoulos and Theoharakis 2001; Katerattanakul et al. 2003; Peffers and Hui 2003; Rainer and Miller 2005; Lamp 2006). Various authors have used citation analysis to evaluate journal value which in turn has been used to propose various IS journal rankings (Holsapple et al. 1993; Holsapple et al. 1994; Katerattanakul and Han 2002; Katerattanakul et al. 2003). IS journal ranking 
has also been reported from a regional perspective where journal readership within geographical areas can impact on rank and hence perceived journal standing and reputation (Avgerou et al. 1999; Mylonopoulos and Theoharakis 2001; Lowry et al. 2004). Other authors, such as Rainer and Miller (2005), after examining a series of IS journal rating studies derived a composite IS journal listinga best of the best so to speak. Rainer and Miller also identified these IS journals as relating to four areas of application — computer science, pure IS/business IS, management and operations.

One study that captured a global publication diversity in the IS sphere was by Peffers and Ya (2003). This study alluded to the universe of outlets for IS research. The authors identified 326 journals that were segmented into several tiers of perceived quality associated with whether the journals were associated directly with information systems, an allied IS area, or were professional/managerial based magazines. The identification of such a high number of journals was facilitated by a methodology that allowed respondents to name and rate journals as an extension to an initial list used in the study. Furthermore, the study was noted to represent the values of academics across a spectrum of disciplines that included computer science, science and engineering, information systems, economics, management, social science and operations research. The Peffers and Ya (2003) study is significant for the large number of IS-related publishing outlets identified, however, the authors do not indicate how academics perceived journals on the basis of country of origin or where their universities were located.

With respect to determining the views and values associated with Australian IS journal output, no investigation or research has directly focussed on this academic area. Recent work by Pervans and Shanks (2006) captured the views of Australian Heads of Information Systems Schools across various areas of IS-related activity which also included journal output performance. From their cohort of respondents the authors were able to determine that each School published on average 9.8 peer-reviewed journal articles per year. The study did not report any associated rating or value system associated with the types of journals in which articles were published.

Mylonopoulos and Theoharakis (2001) identified a set of high ranking IS journals based on the perceptions of a geographical audience that included Australian academics. From a total sample of 979 respondents, some 15\% ( $\mathrm{N}=150)$ were representative of academics from the Australasia region - allowing the views of Asian, New Zealand and Australian scholars on journal standing to be captured. The study used a popularity measure to determine the journal ranking of a set of IS journals with Australasian academics found to have notable similarities and differences in the manner they viewed their journals when compared to their North American and European counterparts. Indeed, the authors concluded that researchers from different regions tend to have diverse approaches to conducting research. Furthermore, the study identified that almost one third of Australasian academics perceived journal ranking lists as an important instrument associated with, or used in, promotional type activities. The study was one of the first to identify journals that were perceived to be important to Australasian IS academics.

Lowry et al (2004) conducted a journal ranking study that represented the views of 2559 academics and practitioners from 414 IS departments drawn from a global audience. Similar to Peffers and Ya (2003), the study captured the perceptions of respondents across a spectrum of disciplines that ranged from communication, engineering, mathematics, business, informatics, pure information systems and computer science. The study also reported the views of journal standing from a geographical perspective with Australasia representing some $20 \%(\sim 510)$ of the respondents. With respect to the Australasian and Latin American regions, Lowry et al (2004) asserted that the number of IS researchers from these areas will significantly increase in the future, resulting in new forms and types of IS journals appearing that will be particular to these geographical regions. Across the three mentioned studies, the North American journals predominate with only one regional Australasian journal identifiable, that being the Australian Journal of Information Systems (AJIS). 
The top twenty-five rated Australasia journals identified by Mylonopoulos and Theoharakis (2001) and Lowry et al (2004), as well as the analogous corresponding set of journals from Peffers and Ya (2003), are detailed in Table 1.

Table 1 Summary findings for three recent IS journal rating studies (Key: M\&T - Mylonopoulos \& Theoharakis (2001), P\&Y - Peffers \& Ya (2003), L - Lowry et al (2004)

\begin{tabular}{|c|c|c|c|c|}
\hline Code & Journal Name (ISSN) & M\&T & $\mathrm{P} \& \mathrm{Y}$ & $\mathrm{L}$ \\
\hline CACM & Communications of the ACM (0001-0782) & 1 & - & 3 \\
\hline MISQ & MIS Quarterly (0276-7783) & 2 & 1 & 1 \\
\hline ISR & Information Systems Research (1047-7047) & 3 & 2 & 2 \\
\hline EJIS & European Journal of Information Systems (0960-085X) & 4 & 4 & 7 \\
\hline HBR & Harvard Business Review (0017-8012) & 5 & - & - \\
\hline IEEETrans & IEEE Transactions (various) & 6 & - & 8 \\
\hline $\mathrm{I} \& \mathrm{M}$ & Information \& Management & 7 & $=5$ & 6 \\
\hline JMIS & Journal of Management Information Systems (0742-1222) & 8 & 3 & 4 \\
\hline DSS & Decision Support Systems (0167-9236) & 9 & 7 & 12 \\
\hline ACMTrans & ACM Transaction (various) & 10 & - & 9 \\
\hline MS & Management Science (0025-1909) & 11 & - & 5 \\
\hline SMR & Sloan Management Review (1532-9194) & 12 & - & - \\
\hline DATABASE & Data Base for Advances in Information Systems (1532-0936) & 13 & 8 & - \\
\hline DSI & Decision Sciences (0011-7315) & 14 & - & 14 \\
\hline JSIS & Journal of Strategic Information Systems (0963-8687) & 15 & 16 & 15 \\
\hline ISJ & Information Systems Journal (1350-1917) & 16 & 10 & 10 \\
\hline IJEC & International Journal of E-commerce & 17 & 12 & 17 \\
\hline IEEEComp & IEEE Computer (0018-9162) & 18 & - & - \\
\hline AJIS & Australian Journal of Information Systems* & 19 & 25 & - \\
\hline CAIS & Communications of the AIS (1529-3181) & 20 & $=5$ & - \\
\hline AMJ & Academy of Management Journal (0001-4273) & 21 & - & - \\
\hline $\mathrm{I} \& \mathrm{O}$ & Information \& Organisation (1471-7727) ** & 22 & - & - \\
\hline ACS & ACM Computing Surveys (0360-0300) & 23 & - & - \\
\hline AMR & Academy of Management Review (0363-7425) & 24 & - & - \\
\hline ASQ & Administrative Science Quarterly (0001-8392) & 25 & - & - \\
\hline IT\&P & Information Technology and People (0959-3845) & - & 15 & 18 \\
\hline IS & Information Systems (0306-4379) & - & 21 & 19 \\
\hline JIT & Journal of Information Technology (0268-3962) & - & 40 & 20 \\
\hline JITM & Journal of Information Tech. Management (1042-1319) & - & 27 & 21 \\
\hline JACM & Journal of the ACM (0004-5411) & - & 17 & 22 \\
\hline MISQE & MISQ Executive (1540-1960) & - & - & 23 \\
\hline IPM & Information Processing and Management (0306-4573) & - & 46 & 24 \\
\hline JComp & Journal on Computing (1091-9856) & - & - & 25 \\
\hline JAIS & Journal of the AIS (1536-9323) & - & 9 & - \\
\hline ISF & Information Systems Frontiers (1387-3326) & - & 18 & - \\
\hline JGIM & Journal of Global Information Management (1062-7375) & - & 19 & - \\
\hline MISQD & MISQ Discovery (no ISSN) & - & 20 & - \\
\hline JOEUC & Journal of Organizational \& End User Comp. (1546-2234) & - & 22 & - \\
\hline JGITM & J. of Global Information Tech. Management (1097-198X) & - & 23 & - \\
\hline InfoSci & Informing Science (1521-4672) & - & 24 & - \\
\hline
\end{tabular}

* Name changed in 2003 to Australasian Journal of Information Systems (1449-8618).

** Known as Accounting, Management \& Information Technologies until 2001. 


\section{ACADEMIC JOURNAL PUBLICATION AND THE AUSTRALIAN DEST}

Journal publication output has been alluded to as being one of the more significant indicators of research productivity for the modern day scholar (Koh 2003). Within the realms of Australian university operations, Ramsden (1994) discusses general academic research productivity amongst Australian academics alluding to parameters such as quality, importance, impact and quantityattributes that could be used to evaluate research performance. Impact was deemed to be a measure of influence reflected in citation counts; quality was the perceived value of an article in the eyes of knowledgeable peers; an article's importance required the passing of time for it to be recognised and quantity related to the number of scholarly publications produced as either counts or total pages. Ramsden (1994) further suggested that the number of academic articles published was an important quantity metric in that it could be associated with the impact value of a researcher's output. In terms of measures, quantity is the simplest to gauge and determine and is one that reflects scholarly productivity at an individual and institutional level.

When capturing aspects of Australian academic productivity, the onus rests with individual universities to manage, administer and record their scholarly research activities if they wish to be rewarded by Government. To record and address scholarly publication output, Australian universities engage in an annual Higher Education Research Data Collection (HERDC), that groups scholarly works into four types- books, book chapters, journal articles and conference publications. In effect the data collection reflects the scholarly publishing activities of Australian academics for which their university is able to receive a compensatory return from the Australian government (DEST 2006). Furthermore, when collecting publication data, academic works can be grouped into various domains to address the research field, educational course and/or an academic discipline (RFCD). Although the allocation of an RFCD code to a publication is not a compulsory requirement for DEST quantum returns, many universities collect this classifying information because it gives them a relatively accurate and representative indication of scholarly activities undertaken across specific research areas (ARC 2005). One research area in the HERDC process that groups publications in an Information, Computing and Communication Sciences domain is the 280000 division - a division that could be viewed as representing the general research area associated with IS. This division allows authors to classify their work into specific fields associated with information systems, computation theory and mathematics, artificial intelligence, signal and image processing, computer software and data format. Furthermore, two other RFCD divisions that address business aspects of the IS area - electronic commerce (RFCD 350213) and business information systems (RFCD 350202) - are also relevant to this study. Hence, a broad spectrum of discipline areas defines the IS-sphere in this paper. Furthermore, the annual HERDC activity amongst the higher education sector in Australia provides a significant data source in allowing the investigation of individual divisions and/or single disciplines to determine the journal publication diversity for that particular area. Moreover, the compliance requirements placed on universities to maintain rigid data integrity for this type of data collected makes the data an extremely reliable and reflective resource (for an explanation of acceptable journal definitions and peer-view criteria associated with DEST see Lamp 2006).

\section{The pending Australian research quality framework (RQF)}

The Australian research quality framework (RQF) is scheduled for introduction in 2008. A basic tenet underlying the Australian Government's introduction of the RQF is the way that research is assessed - moving from a quantitative to a qualitative focus. The new RQF aims are admirable and include the comparison of academic research with international benchmarks, as well as 
endeavouring to assure that public money is achieving the appropriate research outcomes (Bishop 2006). The impacts of the RQF on individual academics are numerous - however, one important issue when it comes to journal output is a notable shift from productivity to quality.

In preparing for the RQF, the Australian Council of Professors and Heads of Information Systems (ACPHIS) in conjunction with AAIS (Australasian Association for Information Systems), has proposed a list of 61 journals that can be viewed as meeting different standards of academic quality in the IS sphere (AAIS 2006). The ACPHIS (2006) journals are structured to reflect different levels of quality based on the their ranking status - Level-A \& B; Non-ranked and Premier Professional Journals. Many of these journals are derived from previous journal ranking studies including the ones previously described in this paper. The Level A set of journals are the definitive publication types that ACPHIS indicates the IS community should aspire to publish in. The 10 Level A journals are Decision Sciences, Decision Support Systems, European Journal of Information Systems, Information Systems Journal, Information Systems Research, Information and Management, Journal of Management Information Systems, Management Science, MIS Quarterly and the Journal of the AIS. ACHPHIS in commenting on academic performance and the RQF suggest that it would not be expected that many scholars in Australia would publish more than one or two articles in these journals. Arguably, the academics that do publish in the Level A journals will have a deservedly outstanding reputation as the best in their field (ACPHIS 2006). The data collect in this study allows an opportunity to explore this ACPHIS issue with respect to Level A publication.

\section{FORMULATING THE RESEARCH QUESTIONS}

The objectives of this paper are to examine available DEST research quantum data to determine the academic journal publication activity in the IS-related areas. The research adopts an exploratory approach to investigating the topic and several questions are used to direct and present the research.

Peffers and Ya (2003) identified a relatively high number $(\mathrm{N}=326)$ of different journals that were perceived to appropriate to publish IS research. In this study the identification of the total number of publication outlets can be considered to represent the diversity of journals used by Australian-based academics to publish IS-related articles. Thus, the first research question (RQ1) posed is:

What journal outlets are used by Australian academics to publish IS-related research?

The first question can be expanded to determine the most popular journals in which academics have published. Determining the popular journal publications from a historical perspective identifies the actual, rather than the perceived journal values of academics. This output could be also viewed as an indicator of preferred journal forums. Hence, the second research question (RQ2) posed is:

Which journals have been most preferred by Australian academics for article publication as measured by the total number of articles published in each journal?

Given the previously global studies capturing the perceptions of academics with respect to journal ranking, the third question posed examines the general performance of Australian scholars compare to ranked journal lists. The question (RQ3) posed:

To what degree have Australian academics published in the highly rated journals identified in previously reported studies (Mylonopoulos and Theoharakis 2001; Peffers and Ya 2003; Lowry et al. 2004)?

With the pending RQF approaching, it becomes relevant to examine the performance of academics against the ACHPIS-identified Level A journals (the limitations of the study prevents an evaluation against the full set of journals). Hence, the question (RQ4) posed: 
To what degree have Australian academics published in the Level A journals identified by ACHPIS (2006)?

\section{METHODOLOGY}

Australian universities are rewarded for their research output and engage in an annual Higher Education Research Data Collection (HERDC) process to validate and report their scholarly works. Part of the process associated with HERDC is to group publications in various RFCD divisions- a process that although not compulsory, many universities use in order to gauge the range of research areas their academics engage. With respect to DEST-collected data, there is no common data repository that allows the respective data sets to be united to reflect the collective publication output of all Australian universities - this output is held in what could be viewed as isolated data islands by each university. Hence, the individual DEST collections of Australian universities formed the domain from which data for this research was sourced.

\section{Sourcing and procuring the data}

All Australian universities ( $\mathrm{N}=38$ ) were approached to participate in the study by providing data associated with academic publishing output. The information systems publication data of interest was drawn from refereed journal publications (commonly coded C1) that had been grouped in the 280000 (Information, Computing and Communication Sciences), 350202 (Business Information Systems) or 350213 (Electronic Commerce) RFCD divisions. The fields requested for each journal record included attributes such as ISSN, journal and article title, publisher and number of pages published for a five-year data-collection period (2001- 2005). Moreover, in order to minimise transcription errors and assist with easier consolidation and evaluation of data, universities were asked to supply their data in spreadsheet format. Data was sourced between October and December 2006.

\section{Examining the data for correctness}

Each university's data set was examined for anomalies, duplication or errors and involved eliminating data records that had a crucial field missing such as the journal title and removing data records data that were not part of the requested RFCD codes.

It was noted that some journal titles did not have an obvious or typical affiliation with themes relevant to the research. When an atypical IS journal title was encountered, the article associated with the journal was examined to confirm that it was an IS-related article and that this entry was not an RFCD classification error. For example, a data record that listed a journal such as The Australian Family Physician would have the associated article examined to see that it related to a computing theme. If the article was deemed by the researcher to be non-IS in nature, it was assumed that the record had been erroneously grouped and was eliminated. Once all individual university data sets were consolidated, article records were examined for duplicate listings.

\section{RESULTS}

Fourteen of Australia's 38 universities responded to a request to provide data for the study, representing a $36.8 \%$ participation rate. The universities that participated in the study included the 
following groupings (AEN 2006) — Group of Eight ( $\mathrm{N}=3$ ), Australian Technology Network (N=2), New Generation Universities ( $\mathrm{N}=2)$, Innovative Research Universities $(\mathrm{N}=2)$ and the regional/other universities $(\mathrm{N}=5)$.

A total of 1449 journal articles were identified across the 14 universities as having published ISrelated themes. These articles were published between 2000 and 2005 and represent a total of 60 years of collective academic article output across the 14 participating universities. It should be noted that because each university had a different approach to data grouping, there was variability in the annual data supplied by each university. Hence, not all universities provided a complete set of journal publication records associated with all years between 2000 and 2005. Indeed, many universities indicated that it had only become a recent practice to classify publications within their RFCD grouping.

The total number of journal records supplied by each university was variable and reflected the relative IS activities within that university. It can only be assumed that universities that had a large and well-established sphere of IS activity had a greater output than those universities in which IS had a secondary or low research focus. The average number of journals published across the 14 universities for the 60 years of data collection was 24.15 articles per year. However, there was a significant variation amongst individual universities in terms of the average number of journal articles published per year with the greatest number of articles publish being 61.0 and the least 6.3. Table 2 summarises the journal publication data used in this study.

Table 2 Summary of Australian university publication data

\begin{tabular}{|c|c|c|c|c|}
\hline $\begin{array}{c}\text { University } \\
\text { Code }\end{array}$ & $\begin{array}{c}\text { Data } \\
\text { collection } \\
\text { period }\end{array}$ & $\begin{array}{c}\text { Years of } \\
\text { output } \\
\text { (N) }\end{array}$ & $\begin{array}{c}\text { Number of } \\
\text { DEST articles } \\
\text { (N) }\end{array}$ & $\begin{array}{c}\text { Average journal } \\
\text { articles per year }\end{array}$ \\
\hline A & $2000-2005$ & 5 & 305 & 61.0 \\
\hline B & $2001-2005$ & 5 & 280 & 56.0 \\
\hline C & $2001-2005$ & 5 & 160 & 32.0 \\
\hline D & $2002-2005$ & 4 & 116 & 29.0 \\
\hline E & $2000-2005$ & 6 & 111 & 18.5 \\
\hline F & $2000-2005$ & 6 & 84 & 14.0 \\
\hline G & $2004-2005$ & 2 & 78 & 39.0 \\
\hline H & $2001-2005$ & 5 & 76 & 15.2 \\
\hline I & $2001-2005$ & 5 & 70 & 32.0 \\
\hline J & $2004-2005$ & 2 & 64 & 6.4 \\
\hline K & $2001-2005$ & 5 & 32 & 6.3 \\
\hline L & $2002-2005$ & 4 & 29 & 9.5 \\
\hline M & $2002-2005$ & 4 & 25 & 19 \\
\hline N & $2004-2005$ & 2 & & \\
\hline
\end{tabular}

\section{RQ1 What journal outlets are used by Australian academics to publish IS-related research?}

An examination of the 1449 journal articles indicates that academics across the 14 universities published articles associated with IS-related research in 649 different journals (The full set of identified journals and the number of articles published in each is listed in the appendix). The total number of different journals identified in this research surpasses the number (326) identified by Peffers and Ya (2003) in their global study of IS publication outlets. The identification of a high 
number of different journals represents the universe of journals that Australian academics have used to publish their IS-related research over the 2000-2005 period.

In examining the distribution of articles published, it was found that 13 journals published $20.2 \%$ of all articles ( $\mathrm{N}=292)$, whilst the remaining 1157 articles $(79.8 \%)$ had a publication distributed across the remaining 636 journals. Table 3 details the articles cumulative distribution values for the 50 most popular journals that published IS-related articles. Notably, 386 IS-related manuscripts were published as one-off articles in different journals. A plot of each individual journal occurrence against the number of articles published in each journal is depicted in Figure 1.

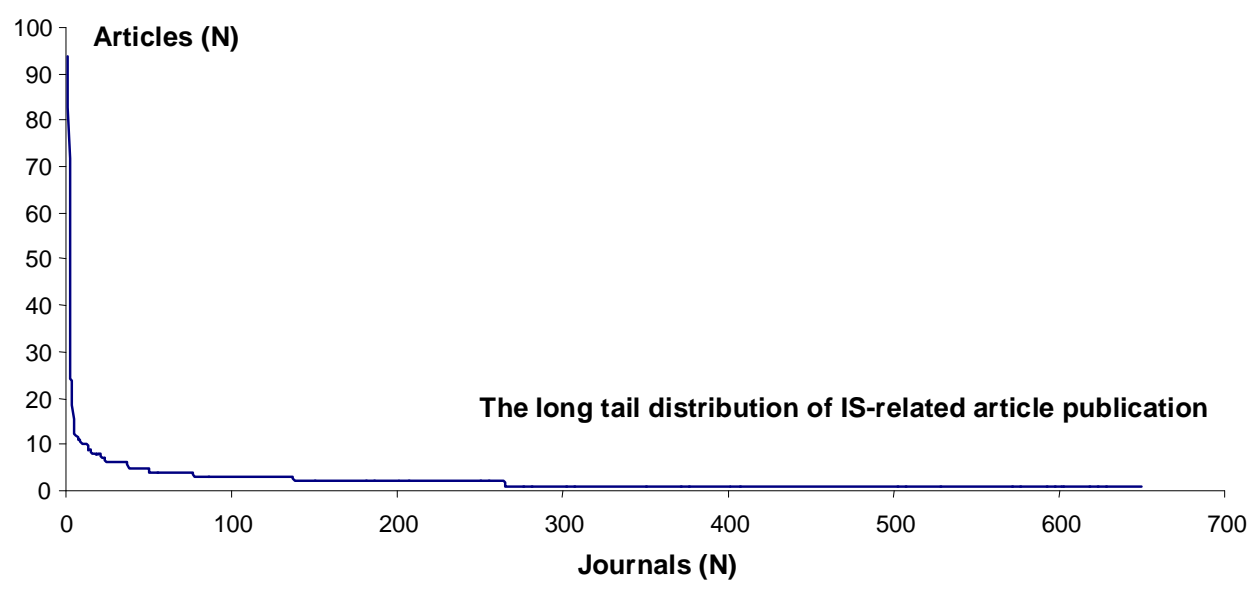

Figure 1 Number of articles published in different journals

This high occurrence of one-off published articles, each in a different journal results in a long tail distribution effect that collectively represents the journal-selection and publishing behaviour of academics. This long tail effect could be viewed as also reflecting the multi-dimensional nature of the IS area where by necessity there needs to be a broad selection of publication outlets to accommodate the varied and distinct scholarly interests. Moreover, this distribution also represents the practicality of a high number of articles not being able to be published in the limited available space of the more popular journals. Indeed, the nature of the IS area is one of rapid development, albeit in technology, change management or business processes - which appear to require a significant diversity of journal publishing venues.

Significantly, the commonly held Pareto phenomenon (the 80:20 rule), where it could be anticipated that $80 \%$ of articles would be associated with some $20 \%$ of available journals, does not appear to hold. In this case, some $20 \%$ of articles are associated with only $2 \%$ of identified journal outlets.

\section{RQ2 Which journals have been most preferred by Australian academics for article publication as measured by the total number of articles published in each journal?}

This research question identifies the popular journals that have been used to publish IS-related scholarly articles. Table 3 lists the top 50 journals that published up to 5 articles by Australian academics across the data collection period. Some observations on the popular journals published include the following:

- The top two journals relate to the computer science sphere and are affiliated with the Springer publishing group. These two journals (Lecture Notes in Computer Science and 
Lecture Notes in Artificial Intelligence) provide a significant outlet for computer science related articles. The modus operandi for considering articles by these two journals is to select cutting edge and pertinent works from high profile conferences allowing the latest and most up-to-date research to be quickly and broadly disseminated.

- Many of the popular manuscript outlets are in journals associated with the Institute of Electrical and Electronics Engineers (IEEE). Indeed, the high number of articles published in these types of journals is arguably an indication of the historical standing the IEEE has amongst its practitioner membership as well as engineering and computer science academics. Moreover, the IEEE provides a broad scope of content coverage and this is reflected in the range of journals available to academics in which they can publish their work. The most popular IEEE journal was Transactions on Signal Processing and Transactions on Information Theory.

- It was observed that 6 of the 50 popular journals were found to specialise in publishing Letters - where 48 articles were published in this type of output (across all 649 journals identified, 12 were Letters). All the Letters journals had an engineering, computer science and or electronics/data processing focus that as a general rule provide an avenue for academics to publish short but informative cutting-edge work. Arguably, there appears to be a lack of this Letters publication type available to academics wishing to publish in the more pure IS-related area.

- The most popular pure or business-related IS journal was the Australasian Journal of Information Systems that published 25 articles. These articles were published by academics affiliated with 10 of the 14 universities that participated in the study. Other popular pure or business-related information systems journals included the Journal of Issues in Informing Science \& Information Technology, Journal of Information Technology, Communications of the AIS and Journal of the American Society for Information Science \& Technology, JITTA and Journal of Strategic Information Systems.

- Six articles were published in Bioinformatics - a journal that tends to reflect the recent interest in computational science and represents the junction of medical-biology and the large data management requirements affiliated with this nascent area.

- Various other notable journals found to be popularly related to software engineering or development (Information and Software Technology, Journal of Systems and Software, International Journal of Software Engineering \& Knowledge Engineering), whilst Scientometrics can be viewed as representing the information and library management sphere of IS-related output.

- Like many previous studies that have identified popular journals in which articles were published, the list is dominated by the USA-North American journals with only three journals (Australasian Journal of Information Systems, Australian Journal of Intelligent Information Processing Systems and Australasian Journal of Combinatorics) having an Australian focus and base. 
Table 3 Most popular 50 journals in which articles were published

\begin{tabular}{|c|c|c|c|c|}
\hline $\mid \begin{array}{c}\text { Journal } \\
\text { Popularity }\end{array}$ & $\begin{array}{c}\text { Journal } \\
\text { Name }\end{array}$ & $\begin{array}{c}\text { Articles } \\
\text { published } \\
\text { (N) }\end{array}$ & $\begin{array}{c}\text { Cumulative } \\
\text { Article } \\
\text { count }\end{array}$ & $\begin{array}{c}\text { Cumulative } \\
\% \\
(\mathrm{~N}=1449)\end{array}$ \\
\hline 1 & Lecture Notes in Computer Science & 94 & 94 & $6.5 \%$ \\
\hline 2 & Lecture Notes in Artificial Intelligence & 52 & 146 & $10.1 \%$ \\
\hline 3 & Australasian Journal of Information Systems & 25 & 171 & $11.8 \%$ \\
\hline 4 & IEEE Transactions on Signal Processing & 24 & 195 & $13.5 \%$ \\
\hline 5 & IEEE Transactions on Information Theory & 13 & 208 & $14.4 \%$ \\
\hline 6 & Electronics Letters & 12 & 220 & $15.2 \%$ \\
\hline 7 & Information and Software Technology & 11 & 231 & $15.9 \%$ \\
\hline 8 & $\begin{array}{c}\text { J of Issues in Informing Science \& Information } \\
\text { Technology }\end{array}$ & 11 & 242 & $16.7 \%$ \\
\hline 9 & Theoretical Computer Science & 11 & 253 & $17.5 \%$ \\
\hline 10 & $\begin{array}{c}\text { International J of Computer Systems Science \& } \\
\text { Engineering }\end{array}$ & 10 & 263 & $18.2 \%$ \\
\hline 11 & Journal of Information Technology & 10 & 273 & $18.8 \%$ \\
\hline 12 & Journal of Systems and Software & 10 & 283 & $19.5 \%$ \\
\hline 13 & Information Processing Letters & 9 & 292 & $20.2 \%$ \\
\hline 14 & $\begin{array}{c}\text { Journal of Research \& Practice in Information } \\
\text { Technology }\end{array}$ & 9 & 301 & $20.8 \%$ \\
\hline 15 & $\begin{array}{c}\text { J of the Am. Society for Information Science \& } \\
\text { Technology }\end{array}$ & 9 & 310 & $21.4 \%$ \\
\hline 16 & $\begin{array}{c}\text { Australian Journal of Intelligent Information Processing } \\
\text { Systems }\end{array}$ & 8 & 318 & $21.9 \%$ \\
\hline 17 & Computer Communications & 8 & 326 & $22.5 \%$ \\
\hline 18 & IEEE Communications Letters & 8 & 334 & $23.1 \%$ \\
\hline 19 & IEEE Transactions on Aerospace \& Electronic Systems & 8 & 342 & $23.6 \%$ \\
\hline 20 & IEEE Transactions on Communications & 8 & 350 & $24.2 \%$ \\
\hline 21 & Systems \& Control Letters & 8 & 358 & $24.7 \%$ \\
\hline 22 & IEEE Computer & 7 & 365 & $25.2 \%$ \\
\hline 23 & IEEE Transactions on Automatic Control & 7 & 372 & $25.7 \%$ \\
\hline 24 & WSEAS Transactions on Computers & 7 & 379 & $26.2 \%$ \\
\hline 25 & Communications of the AIS & 6 & 385 & $26.6 \%$ \\
\hline 26 & IEEE Transactions on Fuzzy Systems & 6 & 391 & $27.0 \%$ \\
\hline 27 & IEEE Transactions on Neural Networks & 6 & 397 & $27.4 \%$ \\
\hline 28 & $\begin{array}{c}\text { IEEE Transactions on Pattern Analysis \& Machine } \\
\text { Intelligence }\end{array}$ & 6 & 403 & $27.8 \%$ \\
\hline 29 & Information Sciences & 6 & 409 & $28.2 \%$ \\
\hline 30 & $\begin{array}{c}\text { International J of Computational Intelligence \& } \\
\text { Applications }\end{array}$ & 6 & 415 & $28.6 \%$ \\
\hline 31 & $\begin{array}{c}\text { Int. J of Software Engineering \& Knowledge } \\
\text { Engineering }\end{array}$ & 6 & 421 & $29.1 \%$ \\
\hline 32 & JITTA: An Information Systems Journal & 6 & 427 & $29.5 \%$ \\
\hline 33 & Journal of Object Technology & 6 & 433 & $29.9 \%$ \\
\hline 34 & Machine Learning & 6 & 439 & $30.3 \%$ \\
\hline 35 & Neurocomputing & 6 & 445 & $30.7 \%$ \\
\hline
\end{tabular}




\begin{tabular}{|l|c|c|c|c|}
\hline 36 & Pattern Recognition Letters & 6 & 451 & $31.1 \%$ \\
\hline 37 & Signal Processing & 6 & 457 & $31.5 \%$ \\
\hline 38 & ACM Transactions on Information Systems & 5 & 462 & $31.9 \%$ \\
\hline 39 & Artificial Intelligence & 5 & 467 & $32.2 \%$ \\
\hline 40 & Australasian Journal of Combinatorics & 5 & 472 & $32.6 \%$ \\
\hline 41 & Automatica & 5 & 477 & $32.9 \%$ \\
\hline 42 & Bioinformatics & 5 & 482 & $33.3 \%$ \\
\hline 43 & Data \& Knowledge Engineering & 5 & 487 & $33.6 \%$ \\
\hline 44 & IEE Proceedings: Vision Image \& Signal Processing & 5 & 492 & $34.0 \%$ \\
\hline 45 & IEEE Signal Processing Letters & 5 & 497 & $34.3 \%$ \\
\hline 46 & IEEE Trans. on Systems, Man \& Cybernetics Part A: Systems \& & 5 & 502 & $34.6 \%$ \\
\hline 47 & Humans & 5 & 507 & $35.0 \%$ \\
\hline 48 & International Journal of Robotics Research & 5 & 512 & $35.3 \%$ \\
\hline 49 & Journal of Strategic Information Systems & 5 & 517 & $35.7 \%$ \\
\hline 50 & Scientometrics & 5 & 522 & $36.0 \%$ \\
\hline
\end{tabular}

\section{RQ3 To what degree have Australian academics published in the highly rated journals identified in previously reported studies?}

Previous studies (Mylonopoulos and Theoharakis 2001; Peffers and Ya 2003; Lowry et al. 2004) identified a set of highly rated IS journals (Table 1). The highly rated IS journals that have been used by Australian academics to publish their articles in the 2000-2005 period are summarised in Table 4. In effect this aspect of the research records the historical scholarly output of Australian academics within the sphere of journals that have been perceived as being of relatively high standing - especially in the pure and business IS areas.

Table 4 Australian Academic publishing in highly rated journals (Key: M\&T - Mylonopoulos \& Theoharakis (2001), P\&Y - Peffers \& Ya (2003), L - Lowry et al (2004)

\begin{tabular}{|c|c|c|c|c|c|}
\hline \multirow[b]{2}{*}{ Code } & \multirow[b]{2}{*}{ Journal Name (ISSN) } & \multicolumn{3}{|c|}{ Journal Rank } & \multirow{2}{*}{$\begin{array}{l}\text { Aust. } \\
\text { Article } \\
\text { s } \\
(\mathrm{N}= \\
1449)\end{array}$} \\
\hline & & $\begin{array}{c}\mathrm{M} \& \\
\mathrm{~T}\end{array}$ & $\begin{array}{l}\mathrm{P} \\
\& \\
\mathrm{Y}\end{array}$ & $\mathrm{L}$ & \\
\hline AJIS & Australian Journal of Information Systems* & 25 & 19 & - & 25 \\
\hline JIT & Journal of Information Technology (0268-3962) & 40 & - & 20 & 10 \\
\hline $\begin{array}{l}\text { IEEECom } \\
\mathrm{p}\end{array}$ & IEEE Computer (0018-9162) & - & 18 & - & 7 \\
\hline CAIS & Communications of the AIS (1529-3181) & 5 & 20 & - & 6 \\
\hline JSIS & Journal of Strategic Information Systems (0963-8687) & 16 & 15 & 15 & 5 \\
\hline ISJ & Information Systems Journal (1350-1917) & 10 & 16 & 10 & 3 \\
\hline IPM & Information Processing and Management (0306-4573) & 46 & - & 24 & 3 \\
\hline ISF & Information Systems Frontiers (1387-3326) & 18 & - & - & 3 \\
\hline CACM & Communications of the ACM (0001-0782) & - & 1 & 3 & 2 \\
\hline EJIS & $\begin{array}{l}\text { European Journal of Information Systems (0960- } \\
\text { 085X) }\end{array}$ & 4 & 4 & 7 & 2 \\
\hline I\&M & Information \& Management & 5 & 7 & 6 & 2 \\
\hline
\end{tabular}




\begin{tabular}{|c|c|c|c|c|c|}
\hline DSS & Decision Support Systems (0167-9236) & 7 & 9 & 12 & 2 \\
\hline $\begin{array}{l}\text { DATABA } \\
\text { SE }\end{array}$ & $\begin{array}{l}\text { Data Base for Advances in Information Systems } \\
\qquad(1532-0936)\end{array}$ & 8 & 13 & - & 2 \\
\hline IJEC & International Journal of E-commerce & 12 & 17 & 17 & 2 \\
\hline IT\&P & Information Technology and People (0959-3845) & 15 & - & 18 & 2 \\
\hline MISQE & MISQ Executive & - & - & 23 & 2 \\
\hline JGIM & $\begin{array}{l}\text { Journal of Global Information Management (1062- } \\
\text { 7375) }\end{array}$ & 19 & - & - & 2 \\
\hline JGITM & $\begin{array}{l}\text { Journal of Global Information Tech. Management } \\
\qquad(1097-198 X)\end{array}$ & 23 & - & - & 2 \\
\hline InfoSci & Informing Science (1521-4672) & 24 & - & - & 2 \\
\hline MISQ & MIS Quarterly (0276-7783) & 1 & 2 & 1 & 1 \\
\hline ISR & Information Systems Research (1047-7047) & 2 & 3 & 2 & 1 \\
\hline JMIS & $\begin{array}{l}\text { Journal of Management Information Systems (0742- } \\
1222)\end{array}$ & 3 & 8 & 4 & 1 \\
\hline IS & Information Systems (0306-4379) & 21 & - & 19 & 1 \\
\hline JOEUC & $\begin{array}{l}\text { Journal of Organizational \& End User Comp. (1546- } \\
\qquad 2234)\end{array}$ & 22 & - & - & 1 \\
\hline $\begin{array}{l}\text { IEEETran } \\
\mathrm{s}\end{array}$ & IEEE Transactions (various) & - & 6 & 8 & $\begin{array}{c}127 \\
\text { (see } \\
\text { table } \\
5 \text { ) } \\
\end{array}$ \\
\hline $\begin{array}{l}\text { ACMTran } \\
\text { s }\end{array}$ & ACM Transaction (various) & - & 10 & 9 & $\begin{array}{c}21 \text { (see } \\
\text { table } \\
5)\end{array}$ \\
\hline
\end{tabular}

* Name changed in 2003 to Australasian Journal of Information Systems (1449-8618).

** Known as Accounting, Management \& Information Technologies until 2001.

An examination of Table 4 indicates that Australian academics associated with 14 universities published a total of 89 articles in 24 journals that were perceived as being highly rated. Placing this finding in the context of the total number (1449) of articles evaluated-some 6\% of the IS-related articles published between 2000 and 2005 were in highly rated IS journals. This equates to an average of $6.36(89 / 14)$ articles per university published in highly related IS journals over the 20002005 period.

Previous studies also identified various transaction journals affiliated with the Association of Computing Machinery (ACM) and the IEEE that had a relatively high standing amongst scholarslisted as $6^{\text {th }}$ and $10^{\text {th }}$ in Table 1 . Within these two transactional areas a total of 157 IS-related articles were published in 46 journals (see Table 5). If one assumes that the popular transaction journals identified are also of a high standing then in terms of total number of articles (1449) it can be said that some $17 \%(\mathrm{~N}=246)$ of articles were published in highly rated journals, with each university over the 2000-2005 period having an average output of 17.57 articles. 
Table 5 IEEE and ACM Transactions publishing Australian IS-related articles

\begin{tabular}{|c|c|c|c|}
\hline IEEE Transactions & $\mathbf{N}$ & ACM Transactions & $\mathbf{N}$ \\
\hline IEEE Tran. on Signal Processing & 24 & ACM Tran. on Information Systems & 5 \\
\hline IEEE Tran. on Information Theory & 13 & ACM Tran. on Database Systems & 3 \\
\hline IEEE Tran. on Aerospace \& Electronic Systems & 8 & $\begin{array}{c}\text { ACM Tran. on Software Engineering \& } \\
\text { Methodology }\end{array}$ & 3 \\
\hline IEEE Tran. on Communications & 8 & ACM Tran. on Computational Logic & 2 \\
\hline IEEE Tran. on Automatic Control & 7 & $\begin{array}{c}\text { ACM Tran. on Programming Languages \& } \\
\text { Systems }\end{array}$ & 2 \\
\hline IEEE Tran. on Neural Networks & 6 & $\begin{array}{c}\text { ACM Tran. on Asian Language Information } \\
\text { Retrieval }\end{array}$ & 1 \\
\hline IEEE Tran. on Pattern Analysis \& Machine Intelligence & 6 & ACM Tran. on Computer-Human Interaction & 1 \\
\hline IEEE Tran. on Fuzzy Systems & 6 & $\begin{array}{c}\text { ACM Tran. on Design Automation of } \\
\text { Electronic Systems }\end{array}$ & 1 \\
\hline $\begin{array}{c}\text { IEEE Tran. on Systems, Man \& Cybernetics Part A: } \\
\text { Systems \& Humans }\end{array}$ & 5 & ACM Tran. on Information \& System Security & 1 \\
\hline IEEE Tran. on Image Processing & 4 & ACM Tran. on Mathematical Software & 1 \\
\hline IEEE Tran. on Knowledge \& Data Engineering & 4 & & \\
\hline $\begin{array}{c}\text { IEEE Tran. on Systems, Man \& Cybernetics Part B: } \\
\text { Cybernetics }\end{array}$ & 4 & & \\
\hline $\begin{array}{c}\text { IEEE Tran. on Systems, Man \& Cybernetics Part C: } \\
\text { Applications \& Reviews } \\
\end{array}$ & 4 & & \\
\hline IEEE Tran. on Biomedical Engineering & 3 & & \\
\hline IEEE Tran. on Circuits \& Systems (Part 1) & 3 & & \\
\hline IEEE Tran. on Circuits \& Systems II - Express Briefs & 3 & & \\
\hline IEEE Tran. on Geoscience \& Remote Sensing & 3 & & \\
\hline IEEE Tran. on Software Engineering & 3 & & \\
\hline IEEE Tran. on Vehicular Technology & 3 & & \\
\hline IEEE Tran. on Wireless Communications & 3 & & \\
\hline IEEE Tran. on Education & 2 & & \\
\hline IEEE Tran. on Speech \& Audio Processing & 2 & & \\
\hline $\begin{array}{c}\text { IEEE Tran. on Very Large Scale Integration (VLSI) } \\
\text { Systems }\end{array}$ & 2 & & \\
\hline IEEE Tran. on Circuits \& Systems for Video Technology & 1 & & \\
\hline IEEE Tran. on Computers & 1 & & \\
\hline IEEE Tran. on Consumer Electronics & 1 & & \\
\hline IEEE Tran. on Dependable \& Secure Computing & 1 & & \\
\hline IEEE Tran. on Evolutionary Computation & 1 & & \\
\hline IEEE Tran. on Industrial Electronics & 1 & & \\
\hline IEEE Tran. on Multimedia & 1 & & \\
\hline IEEE Tran. on Parallel \& Distributed Systems & 1 & & \\
\hline IEEE Tran. on Power Delivery & 1 & & \\
\hline IEEE Tran. on Robotics \& Automation & 1 & & \\
\hline $\begin{array}{c}\text { IEEE/ACM Tran. on Computational Biology and } \\
\text { Bioinformatics } \\
\end{array}$ & 1 & & \\
\hline
\end{tabular}




\section{RQ4 To what degree have Australian academics published in the Level A journals identified by ACHPIS (2006)?}

Twelve articles were published in 7 of the A level journals. The authors $(\mathrm{N}=23)$ contributing to the articles published in this set of journals were associated with 12 different discipline areas as noted by their affiliated faculty, school or area of research. Seven different universities reported articles that were published in Level A journals. No author published in more than one of these journals and 7 of the 12 articles had collaborating authors that were based at a non-Australian university- 9 of the 23 authors (39.1\%) were overseas based. Table 3 summarises the characteristics associated with the Level A journals.

Table 3 ACPHIS Level A Journals: Article characteristics

\begin{tabular}{|c|c|c|c|c|}
\hline Journals & Articles & $\begin{array}{l}\text { Disciplines associated with } \\
\text { contributing authors* }\end{array}$ & $\begin{array}{l}\text { Source } \\
\text { (Uni- } \\
\text { Code) }\end{array}$ & $\begin{array}{l}\text { Author's } \\
\text { academic } \\
\text { level** }\end{array}$ \\
\hline Decision Support Systems & 2 & $\begin{array}{l}\text { Computer Science, } \\
\text { Information Technology, } \\
\text { Management, Computer } \\
\text { Engineering, Business } \\
\end{array}$ & E, L & \multirow{7}{*}{$\begin{array}{c}\text { Professor (os) - } 4 \\
\text { Associate Professor - } 3 \\
\text { Senior Lecturer - } 3 \\
\text { Lecturer - } 3 \\
\text { Professor - } 2 \\
\text { Assistant professor (os) - } \\
2 \\
\text { Associate professor (os) - } \\
1 \\
\text { Director of research - } 1 \\
\text { Lecturer (os) - } 1 \\
\text { PhD Student - } 1 \\
\text { Professorial Fellow (os) - } \\
1 \\
\text { Research Associate - } 1\end{array}$} \\
\hline $\begin{array}{l}\text { European Journal of } \\
\text { Information Systems }\end{array}$ & 2 & $\begin{array}{l}\text { Computing, Information } \\
\text { Systems, Business, } \\
\text { Informatics, Information } \\
\text { Management, } \\
\text { Communications } \\
\end{array}$ & B, D & \\
\hline Information Systems Journal & 3 & $\begin{array}{c}\text { Information Systems, } \\
\text { Information Technology, } \\
\text { Accounting, Management }\end{array}$ & B, C, L & \\
\hline Information Systems Research & 1 & $\begin{array}{c}\text { Information Management, } \\
\text { Information Systems, } \\
\text { Accounting } \\
\end{array}$ & B & \\
\hline Information and Management & 2 & $\begin{array}{c}\text { Business, Information } \\
\text { Management, Information } \\
\text { Systems, Communications, } \\
\text { Library Studies } \\
\end{array}$ & A, D & \\
\hline $\begin{array}{l}\text { Journal of Management } \\
\text { Information Systems }\end{array}$ & 1 & $\begin{array}{c}\text { Information Systems, } \\
\text { Communications, Library } \\
\text { Studies } \\
\end{array}$ & I & \\
\hline MIS Quarterly & 1 & $\begin{array}{c}\text { Information Systems, } \\
\text { Management } \\
\end{array}$ & A & \\
\hline
\end{tabular}

No articles were published in the following ACPHIS identified A level journals- Decision Sciences, Management Science or the Journal of the AIS. *List is one of identification of the different disciplines and does not reflect proportional representation of each discipline. ${ }^{* *}$ No distinction made between chair professor and professor. Overseas (os) authors identified.

This set of Level A journals is consistently noted as a group of quality journals in various ranking studies (AIS 2007). Notwithstanding the low number of articles published in this set of journals some observations are possible:

- In terms of performance and RQF standing, the 12 articles published represents just $0.83 \%$ of the total of 1449 identified articles as forums used by academics to publish their work. Given, that the study reflects some 60 years of output across 14 universities, this findings indicates that many academics - not just those represented by ACPHIS - are not publishing in this select group of journals. 
- ACHPHIS may have made an assumption that the set of Level A journals will implicitly publish articles from the academic constituency that it represents-the pure or business IS area. From this selection of articles, there appears to be a relatively high number of allied disciplines associated with authors that have collaborated on articles.

- There is a relatively high collaboration of Australian based authors with overseas colleagues reflected in the articles published in this set of journals. This may suggest that Australian academics in order to publish in these well known international journals may need to engage collegial collaboration with overseas scholars to facilitate this process.

- There is a diversity of academic levels represented associated with the 23 different authors identified. This aspect of the study tends to suggests that the opportunities to publish articles in these top level journals is not restricted to senior academics such as professors and associate professors.

With the pending RFQ to be introduced in 2008, it can only be assumed that very few academics that are governed by the ACPHIS proposal will be able to claim a quality article in the Level A journals. Furthermore, noting the relatively low number of articles that are annually published by each journal, it is highly commendable that some Australian authors have been successful in publishing articles in this group of journals - in what is undoubtedly a competitive publishing arena. Arguably, the commensurate reward for having published in these types of journals should be one of significant recognition of scholarly status by ACPHIS and associated scholars. Although ACHIS has suggested that Australian IS academics should aspire to publish in these journals, in reality, it is likely that only high achieving academics will publish a small proportion of their articles in these journals across their careers. For some academics the publishing of an article at this level might well be associated with the pinnacle of their career.

\section{CONCLUSION}

This study reported research that evaluated DEST research quantum data from 14 Australian universities for the 2000- 2005 period. It examined journal publication productivity in RFCD areas associated with Information, Computing and Communication Sciences, Business Information Systems and Electronic Commerce. The research is significant in that it is the first study that has reported Australian academic journal publication output in the IS sphere. Moreover, the use of DEST-derived data that forms the basis of the research's investigations is an extremely reliable resource that underpins the foundations of the findings.

Across a composite total of 60 years of academic publishing output, 1449 journal articles were evaluated to identify 649 different journals in which IS-related articles were published. The study identified a long tail distribution of journals, determining that although many journals were popular outlets for academics - a series of one-off IS-related articles were published across 386 different journals. The most popular journals used by Australian academics were the Lecture Notes in Computer Science $(\mathrm{N}=94)$ and Lecture Notes in Artificial Intelligence $(\mathrm{N}=52)$ in the computer science area, with the Australasian Journal of Information Systems $(\mathrm{N}=25)$ being the most popular journal in the pure and business IS sphere. The study also examined publishing output against a set of 50 previously highly rated IS journals. Australian academics were found to have published some $6 \%$ of their output in these previously highly rated journals (up to $17 \%$ if the transaction journals of the IEEE and ACM identified in this study are included in counts). Given that the data was collected over an equivalent time period that totalled 60 academic output years, it can be concluded that the 
average annual publication of articles in these highly rated journals per university occurred at a very low rate.

Furthermore, the study examined the performance of Australian academics against the Level A set of journals proposed by ACPHIS finding that only 12 articles had been published in these journals within the 2000-2005 period. In view of the introduction of the RQF in the 2008, and the importance of the ACPHIS proposal-it can only be assumed that very few academics will be able to claim a quality article performance at this highest ACPHIS level.

\section{Limitations and Future Research}

The main limitation of the study is the university participation rate that only reflects the IS-related publishing output of 14 of Australia's 38 universities. Hence, the study can only really be viewed as a snapshot of the IS-related output and should be interpreted in that context. The participation of a greater number of universities in the study would have arguably resulted in an even broader diversity of journals. The study used a set of RFCD divisions to frame the scope of the study and source DEST data. There may have been other RFCD categories such as librarianship (RFCD 400201) and multimedia (410303) that some academics view as belonging to IS-sphere that where excluded in the study. Hence, the results need to also be considered in the context of the RFCD areas from which data was sourced. The first two research questions are general in their scope and are reported as such, whilst question three, although having a focus on the pure-IS area can still be viewed as exploratory and also general in coverage. Hence, this broad/exploratory approach to investigating IS-related journal output could be viewed as a form of limitation of the study.

Given the diversity of journals identified, future research will examine the identified journals for their impact value as reflected in, for example, the journals derived citation impact factor (ISI ${ }^{\circledR}$ ). Not all journals will have an ISI ${ }^{\circledR}$ value which in itself would be a notable finding. This approach using the ISI ${ }^{\circledR}$ system does have its limitations, however, there is some perception of quality associated with journals that have high citation rates. The research identified a long tail distribution of journals - that represented a significant number of IS-related articles being published in different individual journals. Further investigation of the long tail will allow the identification of niche or specialty areas that may be emerging within the IS-sphere. A cursory examination of the long tail indicates that there may be groupings of articles across different journals that identify health informatics, knowledge management and geographic systems niches. With respect to the ACPHIS list of quality journals, an interesting and relevant extension of this research would be to use the study's data set to evaluate academic performance against the remaining premier professional, level B and NR journals.

\section{REFERENCES}

AEN (2006). The Australian Education Network: Australian University Groupings http://www.australian-universities.com/groupings-of-australian-universities.php [Accessed 11/1/2007].

ARC (2005). Australian Research Council (ARC): Research Fields, Courses and Disciplines Classification (RFCD) Codes http://www.arc.gov.au/apply grants/rfcd codes.htm [Accessed 4/11/2006].

Avgerou C., Siemer J. and Bjorn-Andersen N. (1999). The academic field of Information Systems in Europe. European Journal of Information Systems, 8 (2): pp. 136-153.

Baker M. J. (2000). Writing a Literature Review. The Marketing Review, 1 (2): 219-247. 
Clarke R. (1999). Fundamentals of Information Systems http://www.anu.edu.au/people/Roger.Clarke/SOS/ISFundas.html [Accessed 3/11/2006].

Clarke R. (2006). Key Aspects of the History of the Information Systems Discipline in Australia. Australasian Journal of Information Systems, 14 (1): pp. 123-140.

DEST (2006). Higher Education Research Data Collection: Specifications For The Collection of 2006 Data, Innovation And Research Systems Group Department Of Education, Science And Training (DEST) http://www.dest.gov.au/NR/rdonlyres/830034E5-326A-4961-A02DE3F34407A3F7/12781/DraftHERDC2007.pdf [Accessed 4/11/2006].

Holsapple C. W., Johnson L. E., Manakyan H. and Tanner J. (1993). A Citation Analysis of Business Computing Research Journals. Information and Management, 25 (5): pp. 231-244.

Holsapple C. W., Johnson L. E., Manakyan H. and Tanner J. (1994). Business Computing Research Journals: A Normalised Citation Analysis. Journal of Management Information Systems, 11 (1): pp. 131-140.

Katerattanakul P. and Han B. (2002). Are European IS Journals Under-Rated? An Answer Based on Citation Analysis. European Journal of Information Systems, 12 (4): pp. 60-71.

Katerattanakul P., Han B. and Hong S. (2003). Objective Quality Ranking of Computing Journals. Communications of the ACM, 46 (10): pp. 111-114.

Katerattanakul P., Razi M. A., Han B. and KAM H.-J. (2005). Consistency and Concern on IS Journal Rankings. Journal of Information Technology Theory and Aplication (JITTA), 7 (2): pp. 1-20.

Koh C. E. (2003). IS Journal Review Process: A Survey on IS Research Practices and Journal Review Issues. Information Management, 40 (8): pp. 743-756.

Lamp J. W. (2004). Index of Information Systems Journals, Geelong: Deakin University (http://lamp.infosys.deakin.edu.au/journals/).

Lamp J. W. (2006). Recognition as a Distinguishing Criterion of IS Journals. Australasian Journal of Information Systems, 13 (2): pp. 7-16.

Lowry P. B., Romans D. and Curtis A. (2004). Global Journal Prestige and Supporting Disciplines: A Scientometric Study of Information Systems Journals. Journal of the Association for Information Systems, 5 (2): pp. 29-77.

Mylonopoulos N. and Theoharakis V. (2001). On-Site: Global Perceptions of IS Journals. Communications of the ACM, 44 (9): pp. 29-33.

Peffers K. and Hui W. (2003). Collaboration and Author Order: Changing Patterns in IS Research. Communications of the AIS, 11 (2): pp. 166-190.

Peffers K. and Ya T. (2003). Identifying and Evaluating the Universe of Outlets for Information Systems Research: Ranking the Journals. The Journal of Information Technology Theory and Application, 5 (1): pp. 63-84.

Pervan G. and Shanks G. (2006). The 2005 Survey of Information Systems Research in Australia. Australasian Journal of Information Systems, 14 (1): pp. 273-280.

Rainer K. and Miller M. (2005). Examining Differences Across Journal Rankings. Communications of the ACM, 48 (2): pp. 91-94. 
Ramsden P. (1994). Describing and Explaining Research Productivity. Higher Education, 28: pp. 207-226.

Sharplin A. D. and Mabry R. H. (1985). The Relative Importance of Journals Used in Management Research: An Alternative Ranking. Human Relations, 38 (2): pp.139-149.

Steele C. (2006). Research with Purpose. The Australian Higher Education Section. Sydney, p. 42.

Tenopir C. and King D. W. (2001). Lessons for the Future of Journals. Nature, 413 (6857): pp. 672673.

Vokurka R. J. (1996). The Relative Importance of Journals Used in Operations Management Research: A Citation Analysis. Journal of Operations Management, 14 (4): pp. 345-355.

\section{APPENDIX - LISTING OF 649 JOURNALS PUBLISHING IS-RELATED ARTICLES}

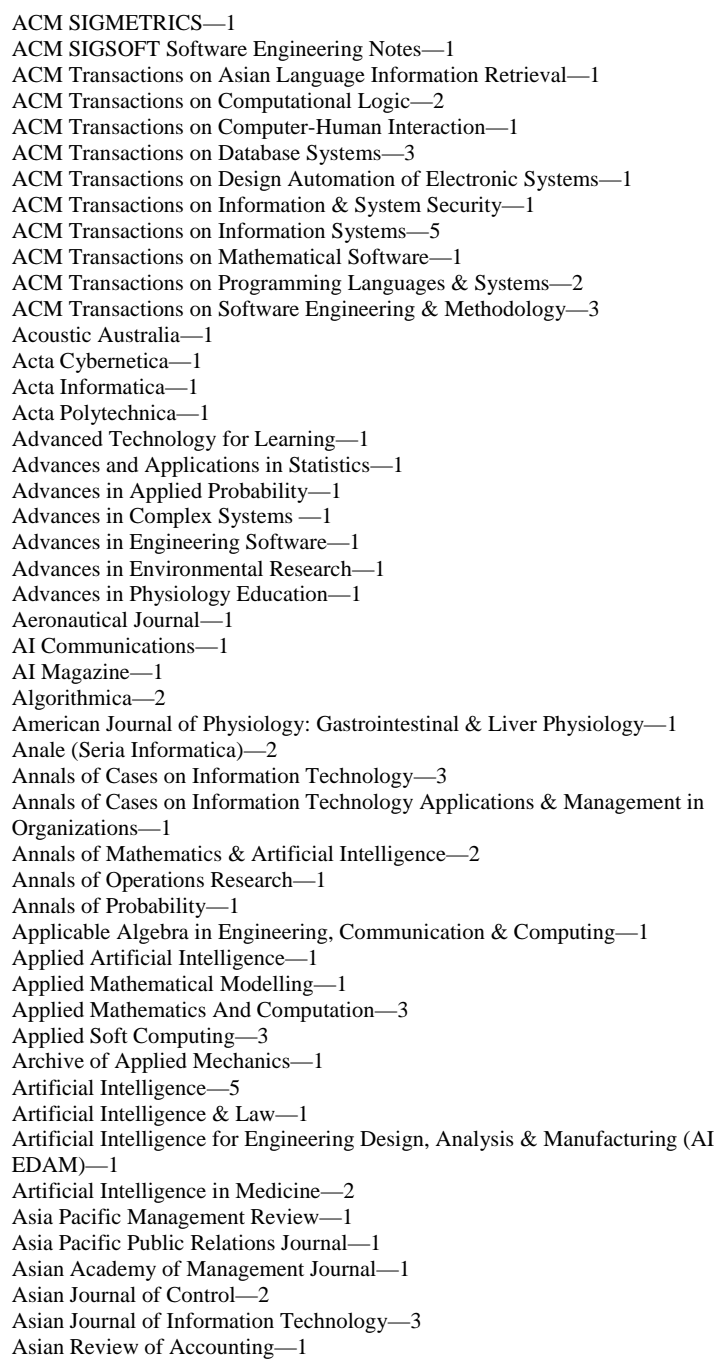


Computer Science Education-1

Computers \& Education-1

Computers \& Electrical Engineering-1

Computers \& Electronics In Agriculture-2

Computers and Graphics-2

Computers and Industrial Engineering-2

Computers and Mathematics with Applications-1

Computers and Security-

Computers and the Humanities-1

Computers in Biology and Medicine-1

Computers in Human Behavior-1

Computers, Environment and Urban Systems-1

Computing and Informatics-1

Computing and Informatics Journal, Special Issue on Grid Computing-1

Computing in Science and Engineering-1

Concurrency and Computation-Practice \& Experience-4

Concurrent Engineering: Research \& Applications-2

Consciousness and Cognition-1

Constraints- 3

Crossroads-1

Cryptologia-4

Current Science-1

Cybernetics and Systems-1

Data \& Knowledge Engineering-5

Data Base for Advances in Information Systems-2

Data Mining and Knowledge Discovery-1

Decision Support Systems-2

Designs Codes and Cryptography-1

Development Southern Africa-

Digital Signal Processing - 2

Discrete Applied Mathematics-1

Discrete Mathematics-3

Distributed \& Parallel Computing-

Distributed \& Parallel Databases-4

Earth Planets and Space-

E-Business Review-1

Ecological Modelling-1

Education and Information Technologies-1

Education for Information-1

Education, Communication and Information-1

Educational Technology \& Society—4

Ejournalist-2

Electronic Commerce Research-1

Electronic Commerce Research \& Applications-4

Electronic Communication Law Review-1

Electronic Journal of Business Research Methods-1

Electronic Journal of Information Systems Evaluation-2

Electronic Journal of Information Systems in Developing Countries-1

Electronic Journal of Knowledge Management-1

Electronic Journal on Information Systems in Developing Countries-1

Electronic Library, The-1

Electronic Notes in Theoretical Computer Science-3

Electronic Transactions on Artificial Intelligence-1

Electronics and Telecommunications Research Institute Journal-1

Electronics Letters-12

Empirical Software Engineering-2

Engineering Applications of Artificial Intelligence-1

Environment \& Planning B: Planning \& Design-2

Environment \& Planning C: Government \& Policy-1

Environmental Science \& Technology-1

e-Service Journal-1

Ethics and Information Technology-2

EURASIP: Journal on Applied Signal Processing - 3

EURASIP:Journal on Wireless Communications \& Networking-1

European Journal of Dental Education-1

European Journal of Information Systems-2

European Journal of Operational Research-2

Evolutionary Computation-1

Expert Systems-1

Expert Systems with Applications-1

Far East Journal of Applied Mathematics-2

Fibonacci Quarterly-1

Finite Fields and their Applications-1

First Monday-2

Forensic Science International-1

Forum: Qualitative Social Research-2

Foundations of Physics Letters-1
Future Generation Computer Systems-2

GeoJournal-1

GESTS International Transaction on Computer Science \& Engineering-1

Global Journal of Flexible Systems Management-1

Graphical Models-1

Graphs and Combinatorics-1

Group Decision and Negotiation-2

Harvard Negotiation Law Review-1

Health Informatics Journal-2

Health Information Management-1

Higher-Order and Symbolic Computation-1

Human Factors-1

IBM Systems Journal-1

IEE Proceedings: Communications-2

IEE Proceedings: Computers \& Digital Techniques-3

IEE Proceedings: Control Theory \& Applications-1

IEE Proceedings: Software-1

IEE Proceedings: Vision Image \& Signal Processing - 5

IEEE Communications Letters- 8

IEEE Communications Magazine-2

IEEE Computational Intelligence Bulletin-1

IEEE Computer-7

IEEE Computer Graphics \& Applications-1

IEEE Geoscience \& Remote Sensing Letters-1

IEEE Intelligent Informatics Bulletin-4

IEEE Intelligent Sysetms-1

IEEE Intelligent Systems-3

IEEE Internet Computing-3

IEEE Journal on Selected Areas in Communications-1

IEEE Multimedia-1

IEEE Network-2

IEEE Photonics Technology Letters-1

IEEE Signal Processing Letters-5

IEEE Software-2

IEEE Transaction on Industrial Informatics-1

IEEE Transactions on Aerospace \& Electronic Systems- 8

IEEE Transactions on Automatic Control-7

IEEE Transactions on Biomedical Engineering-3

IEEE Transactions on Circuits \& Systems (Part 1) -

IEEE Transactions on Circuits \& Systems for Video Technology-1

IEEE Transactions on Circuits \& Systems II - Express Briefs-3

IEEE Transactions on Communications-8

IEEE Transactions on Computers-1

IEEE Transactions on Consumer Electronics-1

IEEE Transactions on Dependable \& Secure Computing-1

IEEE Transactions on Education-2

IEEE Transactions on Evolutionary Computation-1

IEEE Transactions on Fuzzy Systems-6

IEEE Transactions on Geoscience \& Remote Sensing-3

IEEE Transactions on Image Processing - 4

IEEE Transactions on Industrial Electronics-1

IEEE Transactions on Information Theory-13

IEEE Transactions on Knowledge \& Data Engineering-4

IEEE Transactions on Multimedia-1

IEEE Transactions on Neural Networks-6

IEEE Transactions on Parallel \& Distributed Systems-1

IEEE Transactions on Pattern Analysis \& Machine Intelligence-6

IEEE Transactions on Power Delivery-1

IEEE Transactions on Robotics \& Automation-1

IEEE Transactions on Signal Processing-24

IEEE Transactions on Software Engineering-

IEEE Transactions on Speech \& Audio Processing - 2

IEEE Transactions on Systems, Man \& Cybernetics Part A: Systems \&

Humans-5

IEEE Transactions on Systems, Man \& Cybernetics Part B: Cybernetics—4

IEEE Transactions on Systems, Man \& Cybernetics Part C: Applications \& Reviews-4

IEEE Transactions on Vehicular Technology-3

IEEE Transactions on Very Large Scale Integration (VLSI) Systems-2

IEEE Transactions on Wireless Communications-3

IEEE Xplore-1

IEEE/ACM Transactions on Computational Biology and Bioinformatics-1

IEEJ Transactions on Electronics, Information \& Systems-2

IEICE Transactions on Fundamentals of Electronics, Communications \&

Computer Sciences-2

IEICE Transactions on Information \& Systems-1

IMA Journal of Mathematical Control \& Information-1 


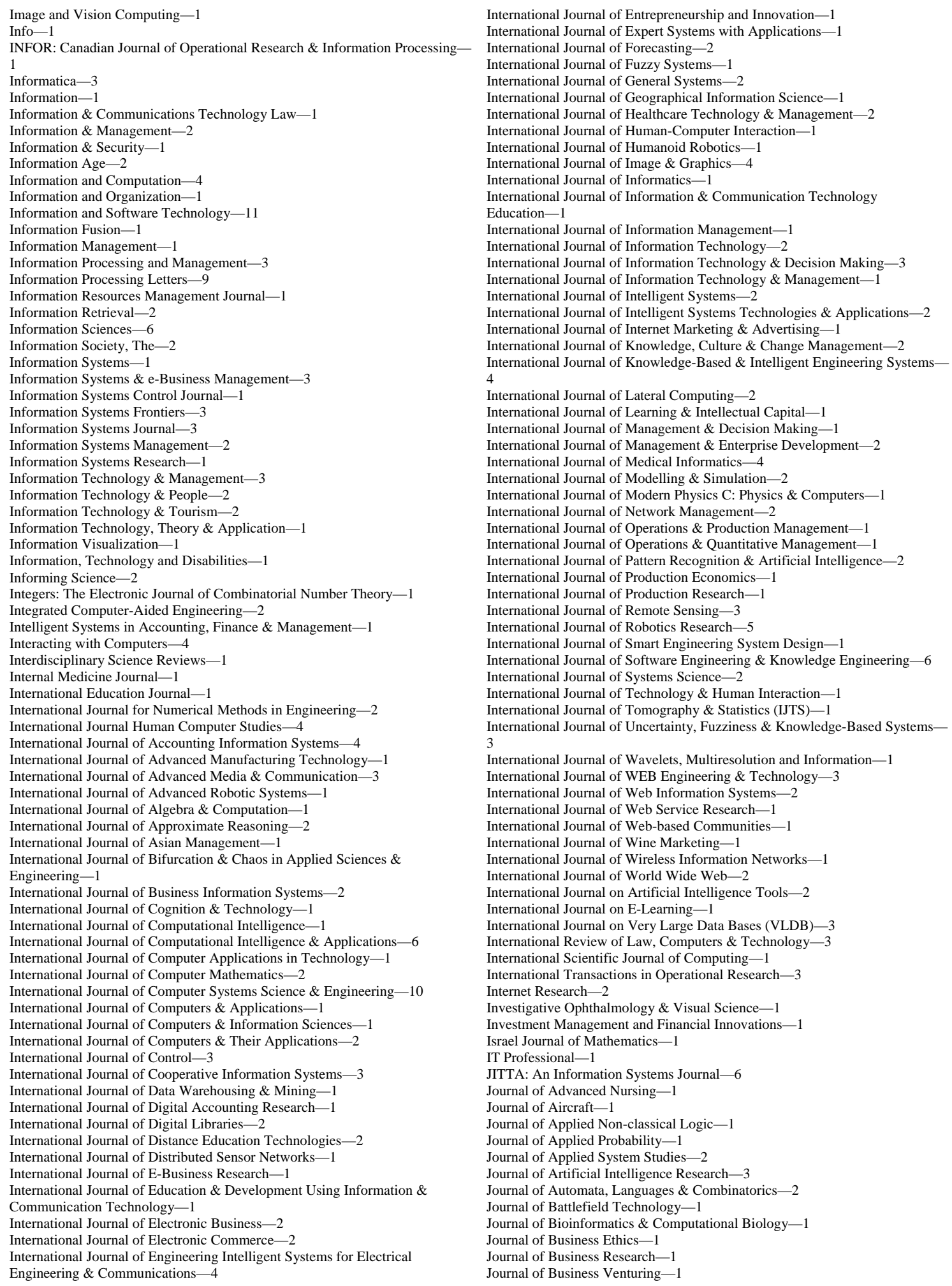


Journal of Chemical Engineering of Japan-1

Journal of College Student Retention: Research, Theory \& Practice-1 Journal of College Teaching and Learning-1

Journal of Combinatorial Designs-1

Journal of Combinatorial Theory, Series A-2

Journal of Communications \& Networks- 1

Journal of Composite Materials-1

Journal of Computer and System Sciences-1

Journal Of Computer Information Systems-1

Journal of Computer Mediated Communication-1

Journal of Computer Science \& Technology - 2

Journal of Computer Security-2

Journal of Contemporary Business Issues-1

Journal of Database Management-3

Journal of Decision Systems-3

Journal of Discrete Algorithms-1

Journal of Electrical \& Electronics Engineering Australia-1

Journal of Electronic Commerce in Organizations-1

Journal of Electronic Commerce Research (Online Edition) - 2

Journal of Electronics \& Information Technology-1

Journal of Emerging Technologies in Accounting-1

Journal of End User Computing -

Journal of Environmental Psychology-

Journal of Experimental Algorithmics-1

Journal of Functional Programming-2

Journal of Geodynamics-1

Journal of Geographical Systems-1

Journal of Global Information Management-2

Journal of Global Information Technology Management-2

Journal of Global Optimization-2

Journal of Global Positioning Systems-2

Journal of Immunological Methods-1

Journal of Industrial \& Management Optimization-1

Journal of Informatics Education Research-1

Journal of Information \& Knowledge Management-3

Journal of Information Science-4

Journal of Information Systems Education-2

Journal of Information Technology-10

Journal of Information Technology Cases \& Applications-1

Journal of Information Technology Education-2

Journal of Information Warfare- 3

Journal of Information, Communication and Ethics in Society-1

Journal of In-Service Education-1

Journal of Integrated Design \& Process Science-1

Journal of Intellectual Capital-1

Journal of Intelligent \& Fuzzy Systems-

Journal of Intelligent Manufacturing-1

Journal of International Development-1

Journal of Internet Technology-2

Journal of Issues in Informing Science \& Information Technology-11

Journal of Knowledge Management Practice-1

Journal of Logic and Computation-2

Journal of Machine Learning Research-4

Journal of Management Development-1

Journal of Management Information Systems-1

Journal of Manufacturing Science \& Engineering-1

Journal of Materials Processing Technology-1

Journal of Medical Systems-1

Journal of Navigation-1

Journal of Network \& Computer Applications-1

Journal of Network Industries-2

Journal of Object Technology-6

Journal of Organizational \& End User Computing-1

Journal of Parallel \& Distributed Computing-2

Journal of Petroleum Science \& Engineering-

Journal of Pharmacy Practice \& Research-1

Journal of Philosophical Logic-2

Journal of Photogrammetry \& Remote Sensing-

Journal of Public Procurement- 1

Journal of Research \& Practice in Information Technology—9

Journal of Security Engineering-3

Journal of Small Business Management-1

Journal of Sociology -1

Journal of Sound and Vibration-

Journal of Strategic Information Systems-5

Journal of Symbolic Logic-1

Journal of Systems \& Information Technology-2
Journal of Systems and Software-10

Journal of Systems Architecture-1

Journal of Systems Science \& Complexity-1

Journal of Systems Science \& Systems Engineering-1

Journal of Technology Management \& Entrepreneurship-1

Journal of Telecommunications \& Information Technology-1

Journal of Telemedicine and Telecare-1

Journal of the Acoustical Society of America-1

Journal of the American Medical Informatics Association-2

Journal of the American Society for Information Science \& Technology—9

Journal of the Australian \& New Zealand Academy of Management-1

Journal of the Energy Institute-1

Journal of Tourism and Cultural Change- 1

Journal of Travel Medicine-1

Journal of Universal Computer Science-2

Journal of Urban Planning \& Development-

Journal of Visual Languages \& Computing-3

Journal of Web Engineering-1

Jurnal Teknologi - Electronics, Control, Telecommunications \& Information

Technology-1

Knowledge and Information Systems - 3

Knowledge Engineering Review-1

Knowledge Management Research \& Practice-1

Knowledge-Based Systems-2

Korean Journal of Computational \& Applied Mathematics-1

Korean Society of Mechanical Engineers (KSME) International Journal-1 Language-1

Language Learning \& Technology-1

Law, Probability and Risk-2

Learning Technology-2

Lecture Notes in Artificial Intelligence-5

Lecture Notes in Computer Science-94

Lecture Notes on Networking \& Mobile Computing-1

Library Hi Tech - 1

Library Management-1

Libri: International Journal of Libraries \& Information Services-1

Linear Algebra and its Applications-1

Literary and Linguistic Computing-

Logic Journal of the IGPL-2

Logistics Information Management-3

Machine Learning-6

Machine Vision and Applications-1

Malaysian Accounting Review-1

Management Case Study Journal-1

Management Research News-1

Managerial Auditing Journal-1

Marketing and Logistics-1

MATCH - Communications in Mathematical \& in Computer Chemistry-1

Mathematics of Computation-1

Medical \& Biological Engineering \& Computing-1

Medical Journal of Australia-1

MIS Quarterly-1

MIS Quarterly Executive-2

Multiagent and Grid Systems-1

Multimedia Tools and Applications-1

Nauchno-Technicheskaya Informatsiya (Seriya 1) -1

Networks-1

Neural Computation-2

Neural Computing \& Applications-1

Neural Information Processing: Letters \& Reviews-3

Neural Networks-

Neural, Parallel and Scientific Computations-1

Neurocomputing - 6

Nonlinear Analysis-

Nordic Journal of Computing-1

Nova Economia-1

Numerical Algorithms-

Nurse Researcher-2

Omega: International Journal of Management Science-1

Online Information Review - 2

Operations Research Letters-1

Optical Engineering - 1

Optics Communications-1

OR Insight-1

Pacific Journalism Review-1

Parallel Algorithms and Applications - 2

Parallel Computing -2 
Parallel Processing Letters-1

Pattern Analysis and Applications-3

Pattern Recognition-4

Pattern Recognition Letters-6

Performance Evaluation-2

Personal and Ubiquitous Computing-3

Perspectives: Policy and Practice in Higher Education-1

Philosophical Psychology-1

Preventive Medicine-1

Problems of Non-Linear Analysis in Engineering Systems-1

Proceedings of the IEEE-3

Production Planning and Control-1

Project Management Journal-1

Prometheus- 3

Publications of the Astronomical Society of Australia-1

Qualitative Research Journal-1

Random Structures and Algorithms-1

Real-Time Imaging - 1

Reference Services Review-1

Research and Development in Higher Education Series-1

Review of Pacific Basin Financial Markets \& Policies-1

Revue d'Intelligence Artificielle-3

Robotics and Autonomous Systems-2

Robotics and Computer-Integrated Manufacturing-1

Ruanjian Xuebao (Journal of Software)-1

Russian Language Journal-1

SCAN-1

Science of Computer Programming-2

Scientometrics-5

SIAM Journal on Computing-2

SIAM Journal on Control \& Optimization-2

SIGCSE Bulletin Inroads-1

Sigmod Record-1

Signal Processing - 6

Signal Processing: Image Communication -4

Simulation-2

Singapore Law Gazette-

Small Business Economics-

Soft Computing-4

Software Process Improvement and Practice-2

Software Quality Journal—2

Software Systems and Modelling-1

Software Testing, Verification \& Reliability-2

Software-Practice \& Experience-5

South African Computer Journal-1

Southern Review-1

Statistica Sinica-1

Statistics and Computing-1

Strategic Change-1
Studia Logica—4

Studies in Learning, Evaluation, Innovation \& Development-2

Supply Chain Management-4

Surveillance \& Society-1

Systemic Practice \& Action Research-1

Systems \& Control Letters-8

Systems Engineering-1

Technological Forecasting \& Social Change-1

Telecommunications \& Networking-1

Telecommunications Journal of Australia-4

Telecommunications Policy-1

Telemedicine Journal and e-Health-2

The Arbitrator and Mediator-1

The British Accounting Review-1

The British Journal for the Philosophy of Science-1

The Grounded Theory Review-1

The International Journal of Information \& Security-1

The Journal of Supercomputing-2

The Journal of the American Taxation Association-1

The Journal of the Institute of Image Electronics Engineers of Japan-2

The Mathematical Gazette- 1

The New Review of Information Behaviour Research-1

The New Zealand Journal of Applied Computing \& Information Technology-2

The Qualitative Report-1

Theoretical Computer Science-11

Theoretical Informatics \& Applications-1

Theory and Practice of Logic Programming - 3

Traffic-1

Trans Tasman Surveyor-1

Transactions in GIS-2

Transformations: Region, Culture and Society -1

UNEAC Asia Papers-1

Universal Access in the Information Society-1

University of Ottawa Law \& Technology Journal-1

Virtual Reality: Research, Development \& Applications-1

Web Intelligence \& Agent Systems-1

Webology-1

Wireless Networks-1

WSEAS Transactions on Acoustics \& Music-1

WSEAS Transactions on Biology \& Biomedicine-2

WSEAS Transactions on Circuits \& Systems-

WSEAS Transactions on Communications-2

WSEAS Transactions on Computers-7

WSEAS Transactions on Electronics-1

WSEAS Transactions on Systems - 3

Yugoslav Journal of Operations Research-1

Zidonghua Xuebao (ACTA Automatica Sinica)—-1 